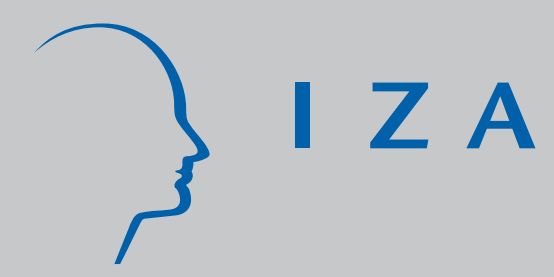

IZA DP No. 3815

Children and Parents Time Use: Empirical Evidence on Investment in Human Capital in France, Italy and Germany

Ana Rute Cardoso

Elsa Fontainha

Chiara Monfardini

November 2008 


\title{
Children and Parents Time Use: Empirical Evidence on Investment in Human Capital in France, Italy and Germany
}

\author{
Ana Rute Cardoso \\ IAE Barcelona (CSIC) and IZA \\ Elsa Fontainha \\ Technical University of Lisbon \\ Chiara Monfardini \\ University of Bologna, CHILD Torino and IZA \\ Discussion Paper No. 3815 \\ November 2008 \\ IZA \\ P.O. Box 7240 \\ 53072 Bonn \\ Germany \\ Phone: +49-228-3894-0 \\ Fax: +49-228-3894-180 \\ E-mail: iza@iza.org
}

\begin{abstract}
Any opinions expressed here are those of the author(s) and not those of IZA. Research published in this series may include views on policy, but the institute itself takes no institutional policy positions.

The Institute for the Study of Labor (IZA) in Bonn is a local and virtual international research center and a place of communication between science, politics and business. IZA is an independent nonprofit organization supported by Deutsche Post World Net. The center is associated with the University of Bonn and offers a stimulating research environment through its international network, workshops and conferences, data service, project support, research visits and doctoral program. IZA engages in (i) original and internationally competitive research in all fields of labor economics, (ii) development of policy concepts, and (iii) dissemination of research results and concepts to the interested public.
\end{abstract}

IZA Discussion Papers often represent preliminary work and are circulated to encourage discussion. Citation of such a paper should account for its provisional character. A revised version may be available directly from the author. 


\title{
ABSTRACT
}

\section{Children and Parents Time Use: Empirical Evidence on Investment in Human Capital in France, Italy and Germany*}

\begin{abstract}
We analyze a mechanism that has been disregarded in the literature on parental investment in children, as little attention has been devoted to the choices made by children themselves. We model directly time use by youngsters into activities related to the acquisition of human capital, considering not just the decision on study time, but also on socialization/networking at young age, which can enhance personal interaction skills. We provide new empirical evidence for three European countries (France, Italy and Germany) on the link between time allocation by parents and time allocation by youngsters, highlighting country-specific patterns as well as cross-country differences. We run fractional regression models and double hurdle models on multi-member household micro data on time use. Countries diverge concerning the association between parents and youngsters allocation of time to socializing and to reading and studying activities, with Italy standing out as the country where that association, in particular between youngster and mother, is strongest. Our results are consistent with different mechanisms: parental role model directly influencing children behavior, intergenerational transmission of preferences, or network effects, as individuals adapt their behavior to social patterns.
\end{abstract}

JEL Classification: J22, J24, J13, C21, C24

Keywords: $\quad$ study time, socializing, networking, youth, intergenerational transmission of preferences, fractional regression models, double hurdle models

Corresponding author:

Chiara Monfardini

Department of Economics

University of Bologna

Piazza Scaravilli 2

40126 Bologna

Italy

E-mail: chiara.monfardini@unibo.it

\footnotetext{
* We are particularly indebted to Dan Hamermesh, and Robert Pollak for comments on previous versions of this paper. We are also grateful to Elena Bardasi, Suzanne Bianchi, Rachel Connelly, Andrea Ichino, to participants in the XXVIII Conference of the International Association of Time Use Research and in the XXII Annual Conference of the European Society for Population Economics for their useful suggestions. This document presents results drawn from the Multinational Time Use Study (MTUS), but the interpretation of the data and other views expressed in this text are those of the authors. This text does not necessarily represent the views of the MTUS team or any agency that has contributed data to the MTUS archive. The authors bear full responsibility for all errors and omissions in the interpretation of the MTUS data.
} 


\section{Introduction}

Children's attainment is influenced by family decisions such as residential location, family stability, and amount of resources allocated to children (see Haveman and Wolfe (1995) for an overview of empirical work on this issue). Parental time is one of the resources that deserved particular attention in the literature, which documented a positive association between parental time and children outcomes later in life (see for example Leibowitz (1974)).

However, the mechanisms linking parental time to children's outcomes are harder to pin down. Indeed, a wide array of unobservable genetic and environmental factors are potentially associated with both the parental decision on time allocated to their children and children's outcomes, thus precluding any causal statement on the impact of parental time on children outcomes. In Price's words, "providing a convincing causal link between parental time inputs and child outcomes has been an elusive search for researchers" (Price, 2008: 243). The attempt to use maternal employment as a proxy for child-care time has been struggling to disentangle the influence of time quantity versus time quality versus changing income on children outcomes. ${ }^{1}$ Confronted with the lack of a reliable identification strategy, the literature has followed a less ambitious line. Price (2008) departs from the result that first born children tend to have better outcomes in life than later siblings, to compare children of the same age but different birth order within similar families, finding that the first-born are allocated more time interacting directly with the parents than the second born. He therefore identifies a potential mechanism for their better outcomes. Other studies have documented the link between the frequency of certain parental activities and children outcomes. For example, indicators of parental time reading to children have been shown to be associated with better children outcomes (Leibowitz, 1977) (Sénéchal and LeFevre, 2002) and time spent having meals together in the family is associated with better adolescent health and well-being (Eisenberg at al, 2004) (Taveras et al, 2005).

The current paper adds to this line of literature by exploring a different link through which parental time use may impact on children outcomes. We focus on the link between time use by parents and time use by their adolescent children into activities related to the acquisition of human capital by the child. We adopt a cross-country perspective that takes advantage of the harmonization of time use data provided by the Multinational Time Use

\footnotetext{
${ }^{1}$ See the results by Ermisch and Francesconi (2002) and Neidell (2000), versus those by O'Brien and Jones (1999), Haveman, Wolfe and Spaulding (1991), Leibowitz (1977), Blau and Grossberg (1992) or DatcherLoury (1988), and the discussion in Cawley and Liu (2007). Ichino and Sanz-de-Galdeano (2005) have called attention to the role of institutions (namely, child care and working time arrangements) as mediators between female labor supply and time devoted to children.
} 
Study (MTUS) project.

We introduce two novel aspects in the analysis. First of all, research has most frequently relied on available data on children's outcomes (such as biometrical and health parameters, school attainment or income later in life) and adults/parents choices, while constrained by lack of information on the children's choices and their own inputs into investment in human capital. Our work models directly time use by young students, a crucial input into the production of their own human capital. By modeling directly time use by young students, we address a major criticism to the literature on the determinants of children's attainment, which states that it has been too focused on the impact of family decisions and circumstances, while not taking into due consideration the impact of "the choices that children make given the investments in and opportunities available to them" (Haveman and Wolfe, 1995: 1836). The relevance of focusing more on the children's actions themselves is also highlighted by O'Brien and Jones (1999), and Bianchi, Robinson and Milkie (2006). Work related to this issue, though from the quite different perspective of parents' decision on time allocation, includes Sttaford and Yeung (2005), who modelled young children's time spent in certain activities in the company of their parent(s) and the intra-household allocation of time with the children.

Secondly, we take into account specific components of human capital that have recently been documented in the literature as relevant. A traditional view of the allocation of time by students would consider that time outside "compulsory activities" such as school attendance and personal tasks (care, sleeping, etc.) could simply be split into time spent usefully -i.e. doing homework and studying-and the remaining time, all assigned to leisure or not directly useful activities. However, both intuition and scientific evidence highlight that human capital includes components other than formal knowledge, namely personal interaction skills and other non-cognitive skills (see extensive work by Heckman and co-authors, namely Heckman, Stixrud and Urzua (2006)). We therefore concentrate on decisions on the allocation of time into study time and socialization/networking at young age. We also consider allocation of time into an activity most often portrayed as having a negative impact on children outcomes: TV watching (see for instance Frey, Benesch and Stutzer (2007) and Vandewater, Bickham and Lee (2006)).

Section 2 searches the literature to address the question "why does parental time allocation impact children's time allocation?" Section 3 presents the data source and section 4 provides descriptive statistics. Section 5 presents the empirical model and section 6 discusses its results, before concluding comments in section 7 . 


\section{Why parental time allocation may impact children time allocation}

There may be an association between time spent by parents in certain activities and time spent by their adolescent children in those activities, with positive (or negative) consequences for the acquisition of human capital by the child. The theoretical literature on time use has seldom dealt with youth decisions. Indeed, the initial and largest strand of this literature has concentrated on the choice between labor and leisure, implicitly having in mind an adult individual. Going beyond the static labor-leisure choice, it has later modeled non-market activities, joint production within the household and intertemporal choices, though without explicit consideration of interactions between parents and adolescents' time use (see the overview in Juster and Stafford, 1991). One must thus turn to other strands of analysis to disentangle the mechanisms that may lead parents' decisions on time use to impact those of their children.

Parents may have a direct influence on the children's behavior by, first of all, influencing preference formation by the child. Theoretical models of intergenerational transmission of preferences have been developed for example by Hill and O'Neill (1994), who refer to the transmission of cultural orientation towards achievement (or preference for investment in human capital), or Lindbeck and Nyberg (2006), who model the transmission of work norms. The work by Fernandez, Fogli and Olivetti (2004) is, to our knowledge, a notable exception that addressed the role model that time allocation by parents may have on children, even though the aim of their analysis is quite distant from the current one. They aim at adding a new channel to explain the rising female labor force participation. According to their model, the allocation of time by mothers would impact on the preferences of the sons - with those whose mother worked being more prone to marry a working woman-, which in turn would lead more women to invest in market skills and participate in the market. On the empirical front, different studies have analyzed intergenerational transmission of preferences, though not focusing on time use. Recent examples include Booth and Kee (2006) on fertility patterns, Loureiro, Sanz-de-Galdeano and Vuri (2006) on smoking habits, Wilhelm et al (2004) on generosity and charity giving, and Bleakley and Chin (2008) on language skills in immigrant families.

Secondly, parental allocation of time may have a direct impact changing children's endowments (which in turn could influence their choices on time allocation). Models of parental investment in children invariably stress the change in children endowments, in particular their human capital, material assets and social capital (see Becker and Tomes, 1986, Leibowitz, 1974 or, more recently, Cunha and Heckman, 2007). Apps and Rees (2002) explicitly underline the role of time invested by parents in shaping the children's 
endowments. Also in the model by Fernandez et al (2004), a working mother can shape the son's skills to perform household work. ${ }^{2}$

Both chains of parental influence on children behavior described above - transmission of preferences or changing endowments - describe a direct impact of parents' behavior on the offsprings' behavior. In particular, the intergenerational transmission of preferences portrays the parental role model directly shaping children's choices. The correlation between parents and children behavior may result from a third -indirect-impact. CalvóArmengol and Jackson (forthcoming) address this point in a model where network externalities are the source of common patterns of behavior for parents and children, as individuals conform to the state of their social community, enjoying higher utility when adopting a behavior that is shared by a large number of their neighbors.

Disentangling which of these channels leads parents' time allocation to have an impact on adolescents' time allocation, using the available data, is not a feasible endeavor. Blow et al (2005) provide a clear review of the econometric methods used to detect the causal impact of parental income on children's outcomes and, while most of the problems they review are pertinent to the analysis of the impact of parental time as well, the solutions reviewed are, in this case, unfeasible. ${ }^{3}$ This work aims instead at documenting that there exists a link between parental time allocation and youngsters' time allocation, which moreover varies across countries, with implications for human capital acquisition by the children.

\section{Data set}

Data from the Time Use Surveys (TUS) for France, Germany and Italy, originally collected by the respective statistical institutes and made available by the Multinational Time Use Survey project (MTUS), are used in this study. ${ }^{4}$ The requirement to match adolescents with their parents living in the same household constrains the set of countries we can study, as several TUS only survey one member of the household.

The TUS contain time allocation variables collected through diaries, as well as demographic and economic variables (for technical characteristics of the three main data

\footnotetext{
${ }^{2}$ The empirical literature on intergenerational mobility has most often concentrated on transmission of education (for a recent overview, see Holmlund, Lindahl and Plug (2008)).

${ }^{3}$ To distinguish the social environment from parental direct influence on children behavior (investment in education), Calvó-Armengol and Jackson (forthcoming) propose using longitudinal data on the social surrounding or data on grand-parents behavior. Beyond the shortcomings that the authors themselves point out (namely, grand-parents behavior could also have a direct effect on the children) and leaving aside the discussion on whether the parental impact thus captured would be due to a role model or some other effect (genetics, for instance), the approach is still not feasible for our analysis of time use behavior, given lack of adequate data.

${ }^{4}$ We have used the dataset version 5.5.2.
} 
sources, see Table A.1 in appendix ${ }^{5}$ ). Most of these data are harmonized by MTUS, allowing comparability across countries. Particularly relevant for our study is the consistency across countries in the codes of activities performed. More than one hundred categories of activities were aggregated by MTUS into 41 activity codes, listed in Table A. 2 in appendix.

The analysis focuses on students aged 15-19. Two main reasons justify this choice. On one hand, at this stage of childhood, individuals are able to make their own choices to a much larger extent than during earlier periods in the lifecycle. On the other hand, by considering this later stage of childhood we can more clearly concentrate on the link between parents' activities and the allocation of time by youngsters, as opposed to earlier periods, when the amount of time spent on child care is a crucial component of parents' time use. To define the border of this late childhood stage we also took into consideration the legal framework, which defines the minimum legal working age in France as 16 years and in Italy and Germany as 15 years, therefore defining a change in the rights and duties of citizens at that age. The sample is further restricted to individuals who are students, not married or cohabiting, without children, living in parental home and with time diary for at least one parent.

Only the time allocated as primary activity is considered. ${ }^{6}$ Only weekdays are considered in the analysis, given the large difference of time allocation patterns between weekdays and weekend days. ${ }^{7}$ The match of the data on youngsters and their parents relied on the household identification code and the relationship between the respondent and the reference person in each household.

The sample sizes are presented in Table A.3 in appendix. The unit of observation is the student and the total sample consists of 2132 students: 846 for France, 650 for Germany and 655 for Italy. For a share of these students, we have data on both parents' time diaries: $81 \%$ in France, and $86 \%$ in Italy and Germany. For the remaining cases, only one of the parents is included in the dataset.

We consider three types of activities, given their impact on human capital formation by students and the potential influence received from parents' behavior: studying and reading; socialization; and watching television. Aggregating from the 41 categories

\footnotetext{
${ }^{5}$ For further documentation, see http://www.timeuse.org/mtus/documentation/ .

${ }^{6}$ Data on secondary activities are also collected by some time use surveys. Secondary activity is an activity that is executed at the same time as another (the primary), and is reported as secondary by the respondents, such as reading as primary activity and listening to music as secondary activity. However, child care is often an individual's "secondary" activity.

${ }^{7}$ For France and Italy, only one diary per person exists in the original data. For Germany there are two diaries per person in MTUS data. For cross country comparison reasons, only one day was selected from the MTUS German data. Since available observations on weekend and week days does not refer to the same individual, we cannot properly investigate any time use substitution pattern between the two kinds of days.
} 
defined by MTUS, we have defined the composition of our categories as follows: studying and reading includes study at home and reading books and newspapers; socializing includes six activities (active sports, civic activities, excursions, cinema and theatre, visiting friends and entertaining friends ${ }^{8}$ ); television watching. Table A.4 in appendix presents in detail the contents of the three categories for children and parents in each country surveyed.

\section{Overview of time allocation by parents and youngsters across countries}

The average time spent daily in each of the three activities by students and their parents is reported in Table 1. Time spent socializing exhibits the lowest average values for each family member in Italy: 38 minutes for students, 26 for the mothers and 19 for the fathers. The German sample presents, on the other hand, the highest values: 72,48 and 46 minutes per day, respectively for students, mothers and fathers. Similarly, when it comes to time spent watching TV, the ranking of countries is consistent across the three types of individuals: students, mothers and fathers. In this case, France presents the highest values, whereas Germany presents the lowest average values. The fact that the ranking of countries in the allocation of time to an activity is the same, irrespective of whether we consider the students, the mothers or the fathers, suggests a consistency in their pattern of behavior, which could be driven by transmission of preferences within the family or conformity to social norms operating within each country. ${ }^{9}$

Table 1. Time allocation (minutes per day), students and their parents

\begin{tabular}{|l|l|ll|ll|ll|}
\hline \multicolumn{2}{|c|}{} & \multicolumn{2}{c|}{ FRANCE } & \multicolumn{2}{c|}{ ITALY } & \multicolumn{2}{c|}{ GERMANY } \\
\cline { 3 - 8 } \multicolumn{2}{|c|}{} & Mean & SD & Mean & SD & Mean & SD \\
\hline \multirow{3}{*}{ Studying and Reading } & Students & 92.7 & $(112.8)$ & 154.3 & $(107.9)$ & 31.0 & $(49.5)$ \\
& Mothers & 20.5 & $(41.2)$ & 15.5 & $(36.4)$ & 44.9 & $(83.4)$ \\
& Fathers & 17.9 & $(40.6)$ & 24.4 & $(46.0)$ & 36.4 & $(63.7)$ \\
\hline \multirow{3}{*}{ Socializing } & Students & 52.2 & $(91.4)$ & 37.7 & $(67.7)$ & 72.1 & $(101.6)$ \\
& Mothers & 30.9 & $(63.7)$ & 26.0 & $(55.6)$ & 47.9 & $(88.1)$ \\
& Fathers & 28.7 & $(65.2)$ & 18.7 & $(55.2)$ & 45.6 & $(81.8)$ \\
\hline \multirow{3}{*}{ TV Watching } & Students & 118.1 & $(106.6)$ & 99.1 & $(75.2)$ & 89.8 & $(90.0)$ \\
& Mothers & 95.5 & $(92.8)$ & 87.8 & $(68.3)$ & 74.9 & $(72.7)$ \\
& Fathers & 116.7 & $(100.6)$ & 105.6 & $(76.8)$ & 91.7 & $(81.3)$ \\
\hline
\end{tabular}

Source: Authors' computation based on MTUS. For the contents of each activity, see Table A.4 in appendix.

The above table refers to the whole population (participants and non participants in an activity), and may hide that some individuals do not engage at all in some activities. A finer analysis would consider separately the participation in an activity and, if participating, the time allocated (see table A.5 in appendix). Watching television is the most participated activity in the three countries, while socialization presents a lower

\footnotetext{
${ }^{8}$ The selection of activities to be included was constrained by data comparability (see table A.4 in appendix). ${ }^{9}$ The comparison across countries of the magnitude of time spent reading and studying is rendered difficult, given the difference in concepts used (note, as described in table A.4, that in Germany this activity does not include time doing homework, thus explaining the lower value in Table 1, whereas it includes time spent with computers).
} 
participation rate. The rate of participation in studying and reading activities is somewhat surprising, as $14 \%$ of the students in Italy declare not to read or study at home; nonparticipation is even higher in France (at 33\%) and in Germany (at 48\%, which could in this case result from the difference in activities included in this category, as described in Table A.4 in appendix). Notice that given the sampling design (observation of one diary per person), the observed participation rates are likely to be affected by the occurrence of "sampling zeros" (people not observed engaging in a given activity in the sampled day). When considering just those individuals who do engage in an activity, we find a rather homogenous share of time allocated to each of the activities, ranging between $4 \%$ and $12 \%$, in every country and for every group of family members. This might suggest that the participation decision and the decision on how much time to allocate are the outcome of two different processes, and must therefore be modeled separately.

Turning to some descriptives that might reveal preliminary evidence on the association pattern between parents and children time use choices, we compare the average share of time allocated by the student into a specific activity splitting the sample of students into two groups: those whose father (mother) allocates into the activity a high share of time (higher than the average time share over that parent) versus the group of students whose father (mother) allocate into the activity a low share of his time (lower than the average). Table 2 shows that the differences between the student group means are always positive and generally statistically different from zero for the three countries. The exception is the socializing activity, where a significant difference of the mean across the two groups emerges only for Italian fathers and German mothers. In general these descriptives therefore suggest that children of parents who allocate a high (low) share of their time to an activity, allocate themselves a high (low) share of their time to that activity. The aim of the multivariate econometric analysis in the following section is to find out whether this positive association between student and parents time use is driven by a set of individual and family characteristics that we can observe in our sample. 
Table 2 - Student time use: comparison of means across groups of parents' time allocation

\begin{tabular}{|c|c|c|c|c|c|c|}
\hline & \multicolumn{2}{|c|}{ France } & \multicolumn{2}{|c|}{ Germany } & \multicolumn{2}{|c|}{ Italy } \\
\hline \multicolumn{7}{|l|}{ STUDY AND READING } \\
\hline Father time use group & obs & $\begin{array}{l}\text { Student } \\
\text { time use } \\
\text { mean }\end{array}$ & obs & $\begin{array}{l}\text { Student } \\
\text { time use } \\
\text { mean }\end{array}$ & obs & $\begin{array}{l}\text { Student } \\
\text { time use } \\
\text { mean }\end{array}$ \\
\hline \multirow{3}{*}{$\begin{array}{l}\text { Time allocated low } \\
\text { Time allocated high } \\
\text { Difference } \\
\text { p-value }\end{array}$} & \multirow{3}{*}{$\begin{array}{l}517 \\
206\end{array}$} & 0.062 & \multirow{3}{*}{$\begin{array}{l}408 \\
168\end{array}$} & 0.020 & \multirow{3}{*}{$\begin{array}{l}400 \\
183\end{array}$} & 0.104 \\
\hline & & 0.076 & & 0.027 & & 0.115 \\
\hline & & $\begin{array}{c}0.014 \\
0.0256\end{array}$ & & $\begin{array}{c}0.007 \\
0.0388\end{array}$ & & $\begin{array}{c}0.011 \\
0.0968\end{array}$ \\
\hline Mother time use group & obs & $\begin{array}{l}\text { Student } \\
\text { time use } \\
\text { mean }\end{array}$ & obs & $\begin{array}{l}\text { Student } \\
\text { time use } \\
\text { mean }\end{array}$ & obs & $\begin{array}{l}\text { Student } \\
\text { time use } \\
\text { mean }\end{array}$ \\
\hline \multirow{3}{*}{$\begin{array}{l}\text { Time allocated low } \\
\text { Time allocated high } \\
\text { Difference } \\
\text { p-value }\end{array}$} & \multirow{3}{*}{$\begin{array}{l}587 \\
218\end{array}$} & 0.060 & \multirow{3}{*}{$\begin{array}{l}456 \\
173\end{array}$} & 0.020 & \multirow{3}{*}{$\begin{array}{l}494 \\
141\end{array}$} & 0.105 \\
\hline & & 0.079 & & 0.026 & & 0.116 \\
\hline & & $\begin{array}{c}0.019 \\
0.0010\end{array}$ & & $\begin{array}{c}0.006 \\
0.0325\end{array}$ & & $\begin{array}{c}0.011 \\
0.1146\end{array}$ \\
\hline \multicolumn{7}{|l|}{ SOCIALIZING } \\
\hline Father time use group & obs & $\begin{array}{l}\text { Student } \\
\text { time use } \\
\text { mean }\end{array}$ & obs & $\begin{array}{l}\text { Student } \\
\text { time use } \\
\text { mean }\end{array}$ & obs & $\begin{array}{l}\text { Student } \\
\text { time use } \\
\text { mean }\end{array}$ \\
\hline \multirow{3}{*}{$\begin{array}{l}\text { Time allocated low } \\
\text { Time allocated high } \\
\text { Difference } \\
\text { p-value }\end{array}$} & \multirow{3}{*}{$\begin{array}{l}547 \\
176\end{array}$} & 0.034 & \multirow{3}{*}{$\begin{array}{l}410 \\
166\end{array}$} & 0.049 & \multirow{3}{*}{$\begin{array}{c}484 \\
99\end{array}$} & 0.024 \\
\hline & & 0.042 & & 0.054 & & 0.039 \\
\hline & & $\begin{array}{c}0.008 \\
0.1511\end{array}$ & & $\begin{array}{c}0.005 \\
0.4133\end{array}$ & & $\begin{array}{c}0.015 \\
0.0039\end{array}$ \\
\hline Mother time use group & obs & $\begin{array}{l}\text { Student } \\
\text { time use } \\
\text { mean }\end{array}$ & obs & $\begin{array}{l}\text { Student } \\
\text { time use } \\
\text { mean }\end{array}$ & obs & $\begin{array}{l}\text { Student } \\
\text { time use } \\
\text { mean }\end{array}$ \\
\hline Time allocated low & 601 & 0.035 & 445 & 0.045 & 470 & 0.025 \\
\hline Time allocated high & 204 & 0.039 & 184 & 0.063 & 165 & 0.030 \\
\hline $\begin{array}{l}\text { Difference } \\
\text { p-value }\end{array}$ & & $\begin{array}{c}0.004 \\
0.4180\end{array}$ & & $\begin{array}{c}0.018 \\
0.0027\end{array}$ & & $\begin{array}{c}0.005 \\
0.2631\end{array}$ \\
\hline WATCHING TV & & & & & & \\
\hline Father time use group & obs & $\begin{array}{l}\text { Student } \\
\text { time use } \\
\text { mean }\end{array}$ & obs & $\begin{array}{l}\text { Student } \\
\text { time use } \\
\text { mean }\end{array}$ & obs & $\begin{array}{l}\text { Student } \\
\text { time use } \\
\text { mean }\end{array}$ \\
\hline Time allocated low & 375 & 0.075 & 323 & 0.054 & 299 & 0.055 \\
\hline Time allocated high & 348 & 0.088 & 253 & 0.071 & 284 & 0.079 \\
\hline $\begin{array}{l}\text { Difference } \\
\text { p-value }\end{array}$ & & $\begin{array}{c}0.013 \\
0.0259 \\
\end{array}$ & & $\begin{array}{c}0.017 \\
0.0009\end{array}$ & & $\begin{array}{l}0.024 \\
0.0000 \\
\end{array}$ \\
\hline Mother time use group & obs & $\begin{array}{l}\text { Student } \\
\text { time use } \\
\text { mean }\end{array}$ & obs & $\begin{array}{l}\text { Student } \\
\text { time use } \\
\text { mean }\end{array}$ & obs & $\begin{array}{l}\text { Student } \\
\text { time use } \\
\text { mean }\end{array}$ \\
\hline Time allocated low & 455 & 0.074 & 344 & 0.048 & 294 & 0.060 \\
\hline Time allocated high & 350 & 0.094 & 285 & 0.079 & 341 & 0.077 \\
\hline $\begin{array}{l}\text { Difference } \\
\text { p-value }\end{array}$ & & $\begin{array}{c}0.020 \\
0.0001\end{array}$ & & $\begin{array}{c}0.031 \\
0.0000\end{array}$ & & $\begin{array}{c}0.017 \\
0.0000 \\
\end{array}$ \\
\hline
\end{tabular}

Source: Authors' computations from Time Use Surveys.

(i) Father (mother) time use group are defined as follows: "Time allocated high", includes students whose father (mother) allocates to a specific activity a time share higher than the average time share (allocated by fathers /mothers to that activity). The group "Time allocated low" is its complement.

(ii) $p$-values from two sample $t$ test. 


\section{Econometric modeling of time use shares}

We estimate different models for the share dedicated by child $i$ to each of the relevant activities: studying and reading (sh_studread), socializing (sh_social), watching TV $\left(s h \_t v\right)$ :

$$
s_{i}^{l}=\frac{t_{i}^{l}}{T_{i}}
$$

where $I=1, \ldots, L$ denotes a specific category of time use; $T_{i}=1440$ is the total amount of time in minutes available within one day. In this framework, the dependent variable is a fraction bounded between zero and one: $0 \leq s_{i}^{l}<1$. Notice that in a typical sample of time diaries, the lower bound will be observed for a non negligible part of the individuals, while the upper bound will never be observed.

Empirical models of time use often specify tobit regressions to tackle the first issue. However, for modeling time use choices, the appeal of the tobit model can be questioned, as the zeros are not the outcome of a censoring mechanism, but they are either due to the sampling process or represent corner solutions. To take into account the share nature of our time use dependent variable, we adopt the fractional regression model proposed by Papke and Wooldridge (1996). This way, we set up a modeling context that can be naturally generalized to allow for the joint analysis of the different time shares. Moreover, the fractional logit presents an important advantage over the tobit specification: it relies on a quasi maximum likelihood estimator, which does not require full normal distributional assumption for consistency. The model builds on the assumptions of correct specification of the conditional mean:

$$
E\left(s_{i}^{l} \mid X_{i}\right)=G\left(X_{i} \beta\right)
$$

where $G(z), 0<G(z)<1$, is any cumulative distribution function and $X_{i}$ represents a set of regressors. Choosing the logistic function as we do leads to the fractional logit model, but other choices are possible and can be subject to RESET-type specification tests. The proposed estimator for $\beta$ is the Quasi Maximum Likelihood Estimator (QMLE; see Gourieroux, Monfort, Trognon, 1984), which maximizes the following Bernoulli quasiloglikelihood function:

$$
l_{i}(\beta)=s_{i} \log \left[G\left(X_{i} \beta\right)\right]+\left(1-s_{i}\right) \log \left[1-G\left(X_{i} \beta\right)\right]
$$

The QMLE is consistent under the conditional mean assumption above, and efficient in the class of QMLEs based on linear exponential family distributions under the additional 
assumption that $\operatorname{Var}\left(s_{i}^{l} \mid X_{i}\right)$ is proportional to $G\left(X_{i} \beta\right)\left[1-G\left(X_{i} \beta\right)\right]$.

The fractional logit model is compatible with the existence of a large number of zero values in the dependent variable, but does not explicitly consider the possibility that the process describing the decision to engage in a given activity might be different from that determining how much time to spend on it. In order to overcome this limitation, we also estimate a two part model (or double hurdle model) where the two decisions are described by different processes. The double hurdle model was introduced originally by Cragg (1971) to model variables having a non-negligible proportion of zero values as the outcome of two different, but possibly related, processes: a participation decision (i.e. whether or not to consume) and a consumption decision (i.e. the level of consumption). Different versions of the model proposed since then in the literature assume different interdependence patterns between the two decision processes (see Jones (1989) for an example modeling cigarette consumption).

Usually, the first part of the model is a binary equation, while the distribution characterizing the second part varies according to the nature of the dependent variable. ${ }^{10}$ In our application, we specify the first part of the model as a logit regression determining the probability that the student $i$ engages in activity $I$ :

$$
\operatorname{Pr}\left(d_{i}^{l}=1 \mid X_{i}\right)=\Lambda\left(X_{i} \delta\right)
$$

where $d_{i}^{l}=1$ if $s_{i}^{l}>0,0$ otherwise.

Through the double hurdle specification, we mainly want to allow the two processes to be different. To this aim, we make the following simplifying assumptions: a) the decision on the amount of time allocated to activity $l$ is independent from the participation decision ${ }^{11}$; b) the observed zeros -i.e. no time spent on a given activity - are only determined by the participation decision, and not by the process determining how much time to spend (first hurdle dominance). Given the fractional nature of our dependent variable, the natural choice for the second part of the model is the fractional logit model presented above: ${ }^{12}$

$$
E\left(s_{i}^{l} \mid X_{i}, s_{i}^{l}>0\right)=\Lambda\left(X_{i} \gamma\right)
$$

\footnotetext{
${ }^{10}$ In models of expenditure, the second part is typically a truncated regression. In health economics there are many applications of two part models where the dependent variables is a count measure describing the use of medical services (see for example Deb and Trivedi (2002)).

${ }^{11}$ We cannot relax this stringent assumption due to the limited information set we have in our data. Estimation of a correlation coefficient would require some exclusion restrictions, to avoid that identification would rely only on functional form.

12 The resulting model is used by Ramalho and Silva (2007) to explain the capital structure decisions of firms (first part: to issue or not debt; second part: how much debt to issue).
} 
With the assumptions of independence and dominance, the first and the second part of the model enter multiplicatively into the likelihood function:

$$
\begin{aligned}
L_{i}(\delta, \gamma) & =\prod_{0}\left[1-\Lambda\left(X_{i} \delta\right)\right] \prod_{>0} \Lambda\left(X_{i} \delta\right) \Lambda\left(X_{i} \gamma\right)^{s_{i}}\left[1-\Lambda\left(X_{i} \gamma\right)\right]^{1-s_{i}} \\
& =\prod_{i}\left[1-\Lambda\left(X_{i} \delta\right)\right] \Lambda\left(X_{i} \delta\right) \prod_{>0} \Lambda\left(X_{i} \gamma\right)^{s_{i}}\left[1-\Lambda\left(X_{i} \gamma\right)\right]^{1-s_{i}}
\end{aligned}
$$

so that the two parts of the model can be estimated separately: the participation process by a logit regression on the whole sample; the second part using the fractional logit QML estimation approach on the sub-sample of positive observations of $s_{i}^{l}$.

\section{Parents and youngsters allocation of time}

Bianchi, Robinson and Milkie (2006: 152) detected a positive association between parents, in particular mothers, allocation of time, and the child's allocation of time (to fitness, reading, housework, and TV watching). However, their analysis relied simply on raw correlations. In our econometric model, the parameters of interest are the partial effects of time allocation by parents on time allocation by youngsters, controlling for a number of observable individual and family characteristics. In the fractional logit models we specify the vector of explanatory variables as $X_{i}=\left(Z_{i}, H_{i}, P_{i}, T I M E_{-} P_{i}^{l}\right)$, where: $Z_{i}$ collects characteristics of the child (sex, age, education); $H_{i}$ includes characteristics of the household (size, single parent household, presence of siblings); $P_{i}$ are controls for parents' age, education and working status (see table A.6 for a description of the control variables). By TIME_ $P_{i}^{l}$ we denote variables describing parents (mother, farther) time allocation into activity $l$, our variables of interest. In the fractional logit model, corresponding to equation (1) of the previous section, we set TIME_ $P_{i}^{l}=s P_{i}^{l}$, where $s P_{i}^{l}$ is the share of time allocated by the parent to activity $I$. In the first part of the double hurdle model (equation 2.a) we let the decision to engage in activity / depend on whether parents engage in the same activity, i.e. we set TIME_ $P_{i}^{l}=d P_{i}^{l}$, where $d P_{i}^{l}$ is a dummy indicating whether $s P_{i}^{l}>0$. In the second part (equation 2.b), we let the amount of time allocated by the student be determined also by the amount of time spent by each of the parents, setting TIME_ $P_{i}^{l}=\left(d P_{i}^{l}, s P_{i}^{l}\right)$.

In the text below, we concentrate on commenting the estimated partial effects (see 
Tables 3 to 8$).{ }^{13}$ Two representative individuals, a male and a female youngster student, are considered when reporting the partial effects. ${ }^{14}$ They share the following attributes: they did not complete secondary education, live in a two parent household, with siblings, mother and father hold secondary education, the father works outside home, and the mother does so in France and Germany, while in Italy she does not work (the modal value). The remaining variables are considered at their mean value within each country. In order to detect possible collinearity problems, we estimate three alternative specifications of the model: with mother characteristics (column headed specification 1), father characteristics (spec 2) and with the characteristics of both parents (spec 3).

Results in Table 5 point to the similarity across countries in the association between parents and children allocation of time to TV watching. Indeed, in every country, both the mother's and the father's share of time spent watching TV has a positive impact on the share of time the youngster allocates to that activity. ${ }^{15}$ This could be the outcome of the synchronization of that activity that often takes place inside the household.

Countries diverge, on the other hand, concerning the influence that parents' have on youngsters when it comes to socializing and to reading and study time (tables 3 and 4). Italy stands out as the country where the influence of parents is more pronounced, in particular that of the mother. Note that in this country, the association between mother's and adolescent child's time allocation extends to every activity considered. In France, mother's share of time reading is associated with more time reading and studying by the youngster (with no influence identified from the father's side), whereas in Germany the father's influence on the reading activity is the relevant one. ${ }^{16}$ Curiously, in terms of socialization, the reverse holds: in Germany, mother's influence is the relevant one when it comes to socializing, while in France it is the father's.

The double hurdle model allows a finer analysis, handling two different processes: whether to engage in the activity and, if so, how much time to allocate it. Again, similarities across countries are highlighted concerning parents' association with youngster's time devoted to watching TV (first part of the double hurdle model in table 8). This could simply reflect the availability or not of a TV set in the household. Progressing to the second stage, where we model how much time youngsters devote to TV watching (given that they watch it), we find across countries a robust association between mother's

\footnotetext{
${ }^{13}$ The full set of estimation results of the fractional logit model and the double hurdle model is available from the authors upon request.

${ }^{14}$ The non linear models estimated allow the partial effect of parents' time use to depend on youngster's gender. We also experimented with a specification including the interaction of youngster's gender with parents' time use variables, which turned out not to be significant.

${ }^{15}$ Even though in France and Germany the significance of the impact of the father's allocation of time is not robust to the introduction of controls for the mother's allocation of time.

${ }^{16}$ Possibly due to the inclusion in this category of time using computers (excluding computer games).
} 
time devoted to TV watching and the adolescent's time devoted to that activity.

The double hurdle model enables clarifications over the fractional logit previously estimated, illustrated in table 6 on the time allocated to study and reading. We find that the father's influence on reading and studying in Germany previously detected operates mostly via the amount of time he devotes to that activity, while in France the relevant factor is whether the mother reads or not. In Italy, how much the mother reads is positively associated with the youngster's behavior.

When modeling time devoted to socializing (Table 7), it is interesting to note again how Italy stands out as the country where parents play the strongest role, in particular the mother. Indeed, whether the father and mother socialize has an impact on whether the youngster socializes. If socializing, the amount of time the youngster devotes to that activity is influenced by the amount of time the mother devotes to the same activity. In Germany, the mother's influence stands out, at both levels of the decision process: whether to socialize and how much time to devote to it.

As stressed in the initial sections, these estimates should not be given a causal interpretation. An endogeneity problem is likely to prevent such an interpretation, due to omitted variables that determine time allocation by children and are at the same time correlated with time allocation by parents. An example of such a variable is the time spent by parents in active care with the child in his early childhood: a parent who likes reading is likely to have spent more time reading to his little child and as a result we will observe the adolescent reading more, even though this is not due to the example of his parent. Also, there might be genetic and environmental unobserved factors that influence the behavior of both the parent and the child. In these situations, our estimates are likely to be over-estimating the causal effect of interest and we are thus emphasizing the comparative analysis across countries trough the MTUS datasets. The estimates we show can only be interpreted as partial effects of time use by parents keeping fixed all the observed variables we control for in the model and provide evidence on the existence of an intergenerational transmission of patterns of time allocation, which could be driven by common influences, preference transmission or a role model of parental behavior influencing directly children's behavior. 
Table 3. Partial effects on the share of time allocated to studying and reading, fractional logit model

\begin{tabular}{|c|c|c|c|c|c|c|}
\hline \multicolumn{7}{|c|}{$100 \times \Delta \mathrm{E}$ (student share time reading) } \\
\hline \multicolumn{7}{|c|}{ ITALY } \\
\hline & \multicolumn{3}{|c|}{ FEMALE } & \multicolumn{3}{|c|}{ MALE } \\
\hline & (spec 1) & (spec 2) & (spec 3) & (spec 1) & (spec 2) & (spec 3) \\
\hline \multirow[t]{2}{*}{ mother share time reading } & $0.283^{\star \star}$ & & $0.256 *$ & $0.245^{\star *}$ & & $0.219 *$ \\
\hline & $(0.131)$ & & $(0.140)$ & $(0.113)$ & & $(0.121)$ \\
\hline \multirow[t]{2}{*}{ father share time reading } & & 0.012 & 0.030 & & 0.010 & 0.026 \\
\hline & & $(0.097)$ & $(0.101)$ & & $(0.083)$ & $(0.087)$ \\
\hline Predicted share & 0.112 & 0.113 & 0.114 & 0.095 & 0.096 & 0.095 \\
\hline \multicolumn{7}{|c|}{ FRANCE } \\
\hline & \multicolumn{3}{|c|}{ FEMALE } & \multicolumn{3}{|c|}{ MALE } \\
\hline & (spec 1) & (spec 2) & (spec 3) & (spec 1) & (spec 2) & (spec 3) \\
\hline \multirow{2}{*}{ mother share time reading } & $0.189^{\star *}$ & & $0.131 *$ & $0.147^{* \star}$ & & $0.099 *$ \\
\hline & $(0.080)$ & & $(0.078)$ & $(0.063)$ & & $(0.059)$ \\
\hline \multirow{2}{*}{ father share time reading } & & -0.021 & -0.082 & & -0.016 & -0.063 \\
\hline & & $(0.102)$ & $(0.101)$ & & $(0.078)$ & $(0.077)$ \\
\hline Predicted share & 0.069 & 0.064 & 0.061 & 0.053 & 0.048 & 0.046 \\
\hline \multicolumn{7}{|c|}{ GERMANY } \\
\hline & \multicolumn{3}{|c|}{ FEMALE } & \multicolumn{3}{|c|}{ MALE } \\
\hline & (spec 1) & (spec 2) & (spec 3) & (spec 1) & (spec 2) & (spec 3) \\
\hline \multirow[t]{2}{*}{ mother share time reading } & 0.026 & & 0.020 & 0.027 & & 0.021 \\
\hline & $(0.018)$ & & $(0.022)$ & $(0.018)$ & & $(0.024)$ \\
\hline \multirow[t]{2}{*}{ father share time reading } & & $0.049 *$ & 0.035 & & $0.051^{*}$ & 0.038 \\
\hline & & $(0.029)$ & $(0.032)$ & & $(0.029)$ & $(0.034)$ \\
\hline Predicted share & 0.019 & 0.021 & 0.021 & 0.019 & 0.022 & 0.023 \\
\hline
\end{tabular}

(i) Three specifications are considered, including respectively: mother characteristics (spec 1), father characteristics (spec 2) and characteristics of both parents (spec 3).

(ii)The reported partial effect is 100 times the variation of the expected share due to a 0.01 (1 percentage point) increase in the parent's share.

(iii)The two reference students did not complete secondary education, live in a two parent household, with siblings, mother and father hold secondary education, the father works and in Germany and France the mother works. The other controls are considered at their mean values in each country.

(iv)Significance levels: *** $1 \%$; $*$ 5\%; * $10 \%$. 
Table 4. Partial effects on the share of time allocated to socializing, fractional logit model

\begin{tabular}{|c|c|c|c|c|c|c|}
\hline \multicolumn{7}{|c|}{$100 \times \Delta \mathrm{E}($ student share time socializing) } \\
\hline \multicolumn{7}{|c|}{$\begin{array}{r}\text { ITALY } \\
\end{array}$} \\
\hline & \multicolumn{3}{|c|}{ FEMALE } & \multicolumn{3}{|c|}{ MALE } \\
\hline & (spec 1) & (spec 2) & (spec 3) & (spec 1) & (spec 2) & (spec 3) \\
\hline \multirow[t]{2}{*}{ mother share time socializing } & $0.088^{\star \star}$ & & $0.067 * *$ & $0.156^{\star \star}$ & & $0.131^{\star \star}$ \\
\hline & $(0.041)$ & & $(0.029)$ & $(0.070)$ & & $(0.054)$ \\
\hline \multirow[t]{2}{*}{ father share time socializing } & & $0.049 \star \star \star *$ & $0.051 * \star \star$ & & $0.089 * \star \star$ & $099 * * *$ \\
\hline & & $(0.019)$ & $(0.019)$ & & $(0.033)$ & $(0.036)$ \\
\hline Predicted share & 0.019 & 0.015 & 0.016 & 0.034 & 0.027 & 0.031 \\
\hline \multicolumn{7}{|c|}{ FRANCE } \\
\hline & \multicolumn{3}{|c|}{ FEMALE } & \multicolumn{3}{|c|}{ MALE } \\
\hline & (spec 1) & (spec 2) & (spec 3) & (spec 1) & (spec 2) & (spec 3) \\
\hline \multirow[t]{2}{*}{ mother share time socializing } & 0.045 & & 0.018 & 0.073 & & 0.028 \\
\hline & $(0.034)$ & & $(0.042)$ & $(0.053)$ & & $(0.065)$ \\
\hline \multirow[t]{2}{*}{ father share time socializing } & & $0.050^{\star}$ & $0.055^{\star}$ & & $0.079^{*}$ & $0.087^{*}$ \\
\hline & & $(0.028)$ & $(0.030)$ & & $(0.044)$ & $(0.047)$ \\
\hline Predicted share & 0.024 & 0.026 & 0.026 & 0.040 & 0.041 & 0.041 \\
\hline \multicolumn{7}{|c|}{ GERMANY } \\
\hline & \multicolumn{3}{|c|}{ FEMALE } & \multicolumn{3}{|c|}{ MALE } \\
\hline & (spec 1) & (spec 2) & (spec 3) & (spec 1) & (spec 2) & (spec 3) \\
\hline \multirow{2}{*}{ mother share time socializing } & $0.143^{\star \star \star}$ & & $0.134^{\star \star \star}$ & $0.182^{\star \star \star}$ & & $0.179 * \star \star$ \\
\hline & $(0.031)$ & & $(0.030)$ & $(0.040)$ & & $(0.040)$ \\
\hline \multirow[t]{2}{*}{ father share time socializing } & & 0.014 & -0.028 & & 0.018 & -0.038 \\
\hline & & $(0.040)$ & $(0.035)$ & & $(0.054)$ & $(0.046)$ \\
\hline Predicted share & 0.038 & 0.039 & 0.035 & 0.049 & 0.054 & 0.047 \\
\hline
\end{tabular}

See notes to Table 3. 
Table 5. Partial effects on the share of time allocated to watching TV, fractional logit model

\begin{tabular}{|c|c|c|c|c|c|c|}
\hline \multicolumn{7}{|c|}{ 100x $\Delta \mathrm{E}$ (student share time TV watching) } \\
\hline \multicolumn{7}{|c|}{$\begin{array}{l}\text { ITALY } \\
\end{array}$} \\
\hline & \multicolumn{3}{|c|}{ FEMALE } & \multicolumn{3}{|c|}{ MALE } \\
\hline & (spec 1) & (spec 2) & (spec 3) & (spec 1) & (spec 2) & (spec 3) \\
\hline mother share TV watch time & $\begin{array}{r}0.201^{\star \star \star} \\
(0.049)\end{array}$ & & $\begin{array}{r}0.159 * \star * \\
(0.059)\end{array}$ & $\begin{array}{r}0.189^{\star \star \star} \\
(0.046)\end{array}$ & & $\begin{array}{r}0.153^{\star \star \star} \\
(0.056)\end{array}$ \\
\hline father share TV watch time & & $\begin{array}{c}0.207^{\star * *} \\
(0.050)\end{array}$ & $\begin{array}{r}0.164^{\star * *} \\
(0.055)\end{array}$ & & $\begin{array}{c}0.198^{\star * \star} \\
(0.048)\end{array}$ & $\begin{array}{r}0.158 * * * \\
(0.053)\end{array}$ \\
\hline Predicted share & 0.069 & 0.069 & 0.068 & 0.065 & 0.066 & 0.066 \\
\hline \multicolumn{7}{|c|}{ FRANCE } \\
\hline & \multicolumn{3}{|c|}{ FEMALE } & \multicolumn{3}{|c|}{ MALE } \\
\hline & (spec 1) & (spec 2) & (spec 3) & (spec 1) & (spec 2) & (spec 3) \\
\hline mother share TV watch time & $\begin{array}{r}0.150^{\star \star \star} \\
(0.037)\end{array}$ & & $\begin{array}{c}0.119^{\star \star \star} \\
(0.048)\end{array}$ & $\begin{array}{r}0.159^{\star \star \star} \\
(0.039)\end{array}$ & & $\begin{array}{l}0.128^{\star \star} \\
(0.050)\end{array}$ \\
\hline father share TV watch time & & $\begin{array}{l}0.097^{\star \star} \\
(0.041)\end{array}$ & $\begin{array}{r}0.043 \\
(0.044)\end{array}$ & & $\begin{array}{l}0.106^{\star \star} \\
(0.044)\end{array}$ & $\begin{array}{r}0.046 \\
(0.047)\end{array}$ \\
\hline Predicted share & 0.077 & 0.085 & 0.080 & 0.081 & 0.094 & 0.087 \\
\hline \multicolumn{7}{|c|}{ GERMANY } \\
\hline & \multicolumn{3}{|c|}{ FEMALE } & \multicolumn{3}{|c|}{ MALE } \\
\hline & (spec 1) & (spec 2) & (spec 3) & (spec 1) & (spec 2) & (spec 3) \\
\hline mother share TV watch time & $\begin{array}{r}0.252^{\star \star \star} \\
(0.041)\end{array}$ & & $\begin{array}{r}0.207^{* \star *} \\
(0.045)\end{array}$ & $\begin{array}{r}0.319 * \star \star \\
(0.052)\end{array}$ & & $\begin{array}{r}0.250 * \star * \\
(0.052)\end{array}$ \\
\hline father share TV watch time & & $\begin{array}{r}0.145^{\star \star \star} \\
(0.043)\end{array}$ & $\begin{array}{r}0.060 \\
(0.042)\end{array}$ & & $\begin{array}{r}0.181^{\star \star \star} \\
(0.054)\end{array}$ & $\begin{array}{r}0.072 \\
(0.050)\end{array}$ \\
\hline Predicted share & 0.055 & 0.055 & 0.054 & 0.071 & 0.070 & 0.067 \\
\hline
\end{tabular}

See notes to Table 3. 
Table 6. Partial effects on time allocated to studying and reading, double hurdle model

\begin{tabular}{|c|c|c|c|c|c|c|}
\hline \multicolumn{7}{|c|}{ ITALY } \\
\hline \multirow[b]{2}{*}{ FIRST PART: $100 x \Delta$ prob(share>0) } & \multicolumn{3}{|c|}{ FEMALE } & \multicolumn{3}{|c|}{ MALE } \\
\hline & (spec 1) & (spec 2) & (spec 3) & $(\operatorname{spec} 1)$ & $(\operatorname{spec} 2)$ & (spec 3) \\
\hline mother reading time (dummy) & $\begin{array}{r}0.042 \\
(0.025)\end{array}$ & & $\begin{array}{r}-0.003 \\
(0.035)\end{array}$ & $\begin{array}{r}0.055 \\
(0.033)\end{array}$ & & $\begin{array}{r}-0.004 \\
(0.048)\end{array}$ \\
\hline \multirow[t]{2}{*}{ father reading time (dummy) } & & 0.035 & 0.033 & & 0.046 & 0.047 \\
\hline & & $(0.027)$ & $(0.024)$ & & $(0.036)$ & $(0.033)$ \\
\hline Predicted prob(positive share) & 0.879 & 0.868 & 0.890 & 0.838 & 0.817 & 0.840 \\
\hline \multicolumn{7}{|l|}{ SECOND PART:100x $\triangle \mathrm{E}($ share|share $>0)$} \\
\hline mother share time reading & $\begin{array}{r}0.465^{\star \star \star} \\
(0.148)\end{array}$ & & $\begin{array}{r}0.593^{\star \star \star} \\
(0.129)\end{array}$ & $\begin{array}{r}0.420^{\star \star \star} \\
(0.131)\end{array}$ & & $\begin{array}{r}0.533^{\star \star \star} \\
(0.116)\end{array}$ \\
\hline \multirow[t]{2}{*}{ father share time reading } & & -0.214 & -0.117 & & -0.191 & -0.106 \\
\hline & & $(0.131)$ & (0.133) & & $(0.118)$ & $(0.120)$ \\
\hline \multirow[t]{2}{*}{ Predicted share } & 0.124 & 0.131 & 0.124 & 0.110 & 0.115 & 0.110 \\
\hline & \multicolumn{6}{|c|}{ FRANCE } \\
\hline \multirow[b]{2}{*}{ FIRST PART: $100 x \Delta$ prob(share>0) } & \multicolumn{3}{|c|}{ FEMALE } & \multicolumn{3}{|c|}{ MALE } \\
\hline & $(\operatorname{spec} 1)$ & $(\operatorname{spec} 2)$ & (spec 3) & $(\operatorname{spec} 1)$ & (spec 2) & (spec 3) \\
\hline \multirow[t]{2}{*}{ mother reading time (dummy) } & $0.112^{\star \star \star}$ & & $0.096^{\star \star}$ & $0.138^{\star \star \star}$ & & $0.122^{\star \star}$ \\
\hline & $(0.033)$ & & $(0.040)$ & $(0.041)$ & & $(0.051)$ \\
\hline \multirow[t]{2}{*}{ father reading time (dummy) } & & 0.028 & 0.013 & & 0.035 & 0.015 \\
\hline & & $(0.039)$ & $(0.045)$ & & $(0.049)$ & $(0.054)$ \\
\hline Predicted prob(positive share) & 0.704 & 0.720 & 0.696 & 0.590 & 0.575 & 0.537 \\
\hline \multicolumn{7}{|l|}{ SECOND PART:100x $\triangle E($ share|share $>0)$} \\
\hline \multirow[t]{2}{*}{ mother share time reading } & 0.116 & & 0.038 & 0.106 & & 0.035 \\
\hline & $(0.166)$ & & (0.160) & $(0.151)$ & & $(0.147)$ \\
\hline \multirow[t]{2}{*}{ father share time reading } & & 0.107 & 0.114 & & 0.098 & 0.105 \\
\hline & & $(0.197)$ & (0.190) & & $(0.179)$ & $(0.174)$ \\
\hline \multirow[t]{2}{*}{ Predicted share } & 0.093 & 0.094 & 0.087 & 0.084 & 0.085 & 0.079 \\
\hline & \multicolumn{6}{|c|}{ GERMANY } \\
\hline \multirow[b]{2}{*}{ FIRST PART:100x $\Delta$ prob(share $>0)$} & \multicolumn{3}{|c|}{ FEMALE } & \multicolumn{3}{|c|}{ MALE } \\
\hline & $(\operatorname{spec} 1)$ & (spec 2) & (spec 3) & $(\operatorname{spec} 1)$ & (spec 2) & (spec 3) \\
\hline \multirow[t]{2}{*}{ mother reading time (dummy) } & $0.101^{\star \star}$ & & $0.117^{\star \star}$ & $0.100^{\star \star}$ & & $0.116^{\star *}$ \\
\hline & $(0.043)$ & & $(0.047)$ & $(0.043)$ & & $(0.047)$ \\
\hline \multirow[t]{2}{*}{ father reading time (dummy) } & & 0.037 & 0.008 & & 0.037 & 0.008 \\
\hline & & $(0.045)$ & $(0.047)$ & & $(0.045)$ & $(0.046)$ \\
\hline Predicted prob(positive share) & 0.449 & 0.506 & 0.441 & 0.414 & 0.459 & 0.407 \\
\hline SECOND PART:100x $\Delta \mathrm{E}($ share|share $>0)$ & & & & & & \\
\hline mother share time reading & 0.046 & & 0.028 & 0.049 & & 0.032 \\
\hline & $(0.039)$ & & (0.045) & $(0.042)$ & & $(0.052)$ \\
\hline father share time reading & & $0.079^{*}$ & 0.063 & & $0.089^{*}$ & 0.072 \\
\hline & & $(0.046)$ & (0.053) & & $(0.053)$ & $(0.061)$ \\
\hline Predicted share & 0.039 & 0.039 & 0.039 & 0.042 & 0.044 & 0.044 \\
\hline
\end{tabular}

(i) FIRST PART: partial effect is 100 times the variation of the probability due to a 0.01 (1 percentage point) increase in the parent's share.

(ii) SECOND PART: partial effect is 100 times the variation of the expected conditional share due to a 0.01 (1 percentage point) increase in the parent's share.

(iii) the two reference students did not complete secondary education, live in a two parent household, with siblings, mother and father hold secondary education, both parents works (only in Italy the mother does not). The other controls are considered at their mean value for each country.

(iv) The dummy indicating parents' activity is set to 0 in the prediction of the probability of positive share.

(v) The partial effect of the parents share is conditional on that share being positive (and evaluated at the mean of the positive values).

(vi) Significance levels: *** $1 \%$; $* \star 5 \%$; * $10 \%$.

(vii)Three specifications are considered, including respectively: mother characteristics (spec 1), father characteristics (spec 2) and characteristics of both parents (spec 3). 
Table 7. Partial effects on time allocated to socializing, double hurdle model

\begin{tabular}{|c|c|c|c|c|c|c|}
\hline \multicolumn{7}{|c|}{ ITALY } \\
\hline \multirow[b]{2}{*}{ FIRST PART: $100 x \Delta$ prob(share>0) } & \multicolumn{3}{|c|}{ FEMALE } & \multicolumn{3}{|c|}{ MALE } \\
\hline & (spec 1) & (spec 2) & (spec 3) & (spec 1) & (spec 2) & (spec 3) \\
\hline mother socializing time (dummy) & $\begin{array}{r}0.132^{\star \star \star} \\
(0.040)\end{array}$ & & $\begin{array}{r}0.073^{\star} \\
(0.040)\end{array}$ & $\begin{array}{r}0.153^{\star \star \star} \\
(0.045)\end{array}$ & & $\begin{array}{r}0.095^{\star} \\
(0.050)\end{array}$ \\
\hline father socializing time (dummy) & & $\begin{array}{r}0.192^{\star \star \star} \\
(0.055)\end{array}$ & $\begin{array}{r}0.170 * \star \star \\
(0.058)\end{array}$ & & $\begin{array}{r}0.229 * * * \\
(0.057)\end{array}$ & $\begin{array}{r}0.207^{\star * *} \\
(0.061)\end{array}$ \\
\hline Predicted prob(positive share) & 0.236 & 0.201 & 0.200 & 0.343 & 0.330 & 0.336 \\
\hline \multicolumn{7}{|l|}{ SECOND PART: $100 \times \Delta E($ share|share $>0)$} \\
\hline mother share time socializing & $\begin{array}{r}0.273^{\star \star \star} \\
(0.068)\end{array}$ & & $\begin{array}{r}0.239 * * * \\
(0.064)\end{array}$ & $\begin{array}{r}0.350 * \star * \\
(0.086)\end{array}$ & & $\begin{array}{r}0.306^{\star \star \star} \\
(0.082)\end{array}$ \\
\hline \multirow[t]{2}{*}{ father share time socializing } & & -0.019 & 0.004 & & -0.023 & 0.005 \\
\hline & & $(0.060)$ & $(0.048)$ & & $(0.072)$ & $(0.061)$ \\
\hline Predicted share & 0.067 & 0.062 & 0.058 & 0.087 & 0.076 & 0.076 \\
\hline \multicolumn{7}{|c|}{ FRANCE } \\
\hline \multirow[b]{2}{*}{ FIRST PART: $100 x \Delta$ prob(share $>0)$} & \multicolumn{3}{|c|}{ FEMALE } & \multicolumn{3}{|c|}{ MALE } \\
\hline & (spec 1) & (spec 2) & (spec 3) & (spec 1) & (spec 2) & (spec 3) \\
\hline mother socializing time (dummy) & $\begin{array}{l}0.070 \star \star \\
(0.036)\end{array}$ & & $\begin{array}{r}0.027 \\
(0.040)\end{array}$ & $\begin{array}{l}0.079 * * \\
(0.040)\end{array}$ & & $\begin{array}{r}0.030 \\
(0.044)\end{array}$ \\
\hline \multirow[t]{2}{*}{ father socializing time (dummy) } & & $0.072^{*}$ & 0.070 & & $0.078^{\star}$ & 0.077 \\
\hline & & $(0.042)$ & $(0.044)$ & & $(0.045)$ & $(0.047)$ \\
\hline Predicted prob(positive share) & 0.288 & 0.329 & 0.312 & 0.410 & 0.448 & 0.430 \\
\hline \multicolumn{7}{|l|}{ SECOND PART: $100 \times \Delta E($ share|share $>0)$} \\
\hline \multirow[t]{2}{*}{ mother share time socializing } & 0.168 & & $0.255^{\star}$ & 0.197 & & $0.298^{\star}$ \\
\hline & $(0.113)$ & & $(0.152)$ & $(0.134)$ & & $(0.179)$ \\
\hline \multirow[t]{2}{*}{ father share time socializing } & & -0.105 & -0.155 & & -0.121 & -0.180 \\
\hline & & $(0.102)$ & $(0.115)$ & & $(0.116)$ & $(0.131)$ \\
\hline Predicted share & 0.073 & 0.077 & 0.078 & 0.086 & 0.090 & 0.092 \\
\hline \multicolumn{7}{|c|}{ GERMANY } \\
\hline \multirow[b]{2}{*}{ FIRST PART: $100 x \Delta$ prob(share>0) } & \multicolumn{3}{|c|}{ FEMALE } & \multicolumn{3}{|c|}{ MALE } \\
\hline & (spec 1) & (spec 2) & (spec 3) & (spec 1) & (spec 2) & (spec 3) \\
\hline \multirow[t]{2}{*}{ mother socializing time (dummy) } & $0.078^{\star}$ & & $0.089 * \star$ & $0.078^{*}$ & & $0.089^{\star \star}$ \\
\hline & $(0.042)$ & & $(0.045)$ & $(0.042)$ & & $(0.045)$ \\
\hline \multirow[t]{2}{*}{ father socializing time (dummy) } & & 0.030 & 0.014 & & 0.029 & 0.014 \\
\hline & & $(0.044)$ & $(0.046)$ & & $(0.044)$ & $(0.047)$ \\
\hline Predicted prob(positive share) & 0.479 & 0.509 & 0.465 & 0.496 & 0.543 & 0.493 \\
\hline \multicolumn{7}{|l|}{ SECOND PART: $100 \times \Delta E($ share|share $>0)$} \\
\hline \multirow[t]{2}{*}{ mother share time socializing } & $0.223^{\star \star \star}$ & & $0.170^{\star \star \star}$ & $0.274^{\star \star \star}$ & & $0.213^{\star \star \star}$ \\
\hline & $(0.058)$ & & $(0.056)$ & $(0.074)$ & & $(0.071)$ \\
\hline \multirow[t]{2}{*}{ father share time socializing } & & $0.171^{\star *}$ & 0.109 & & $0.213^{\star *}$ & 0.136 \\
\hline & & $(0.079)$ & $(0.067)$ & & $(0.095)$ & $(0.083)$ \\
\hline Predicted share & 0.075 & 0.068 & 0.064 & 0.094 & 0.087 & 0.082 \\
\hline
\end{tabular}

See Notes to Table 6. 
Table 8. Partial effects on time allocated to TV watching double hurdle model

\begin{tabular}{|c|c|c|c|c|c|c|}
\hline \multicolumn{7}{|c|}{ ITALY } \\
\hline \multirow[b]{2}{*}{ FIRST PART: $100 x \Delta$ prob(share>0) } & \multicolumn{3}{|c|}{ FEMALE } & \multicolumn{3}{|c|}{ MALE } \\
\hline & (spec 1) & (spec 2) & (spec 3) & (spec 1) & (spec 2) & (spec 3) \\
\hline mother TV watch time (dummy) & $\begin{array}{r}0.151^{\star \star \star} \\
(0.049)\end{array}$ & & $\begin{array}{r}0.192^{\star * *} \\
(0.065)\end{array}$ & $\begin{array}{r}0.186 * \star \star \\
(0.056)\end{array}$ & & $\begin{array}{r}0.205^{\star \star \star} \\
(0.067)\end{array}$ \\
\hline father TV watch time (dummy) & & $\begin{array}{r}0.192^{\star \star *} \\
(0.059)\end{array}$ & $\begin{array}{r}0.229 * \star \star \\
(0.073)\end{array}$ & & $\begin{array}{r}0.234^{\star \star \star} \\
(0.064)\end{array}$ & $\begin{array}{r}0.249 * \star * \\
(0.072)\end{array}$ \\
\hline Predicted prob(positive share) & 0.720 & 0.681 & 0.545 & 0.634 & 0.588 & 0.463 \\
\hline \multicolumn{7}{|l|}{ SECOND PART: $100 \times \Delta \mathrm{E}($ share $\mid$ share $>0)$} \\
\hline mother share time TV watch & $\begin{array}{r}0.222^{\star \star \star} \\
(0.065)\end{array}$ & & $\begin{array}{r}0.227^{\star \star \star} \\
(0.074)\end{array}$ & $\begin{array}{r}0.222^{\star \star \star} \\
(0.064)\end{array}$ & & $\begin{array}{r}0.229 * \star \star \\
(0.072)\end{array}$ \\
\hline father share time TV watch & & $\begin{array}{c}0.099 * \\
(0.057)\end{array}$ & $\begin{array}{r}0.051 \\
(0.066)\end{array}$ & $0.100^{*}$ & $\begin{array}{r}0.051 \\
(0.058)\end{array}$ & $(0.066)$ \\
\hline Predicted share & 0.086 & 0.084 & 0.087 & 0.086 & 0.085 & 0.087 \\
\hline \multicolumn{7}{|c|}{ FRANCE } \\
\hline \multirow[b]{2}{*}{ FIRST PART: 100x $\Delta$ prob(share>0) } & \multicolumn{3}{|c|}{ FEMALE } & \multicolumn{3}{|c|}{ MALE } \\
\hline & (spec 1) & (spec 2) & (spec 3) & (spec 1) & (spec 2) & (spec 3) \\
\hline mother TV watch time (dummy) & $\begin{array}{r}0.156^{\star \star \star} \\
(0.043)\end{array}$ & & $\begin{array}{c}0.134^{\star *} \\
(0.052)\end{array}$ & $\begin{array}{r}0.131^{\star \star \star} \\
(0.038)\end{array}$ & & $\begin{array}{c}0.117^{* *} \\
(0.048)\end{array}$ \\
\hline father TV watch time (dummy) & & $\begin{array}{r}0.204^{\star \star \star} \\
(0.050)\end{array}$ & $\begin{array}{r}0.160 * \star \star \\
(0.057)\end{array}$ & & $\begin{array}{r}0.166^{\star \star \star} \\
(0.044)\end{array}$ & $\begin{array}{r}0.139 * * * \\
(0.052)\end{array}$ \\
\hline Predicted prob(positive share) & 0.648 & 0.590 & 0.547 & 0.722 & 0.689 & 0.644 \\
\hline \multicolumn{7}{|l|}{ SECOND PART: $100 \times \Delta E($ share|share $>0)$} \\
\hline mother share time TV watch & $\begin{array}{l}0.118^{\star \star} \\
(0.050)\end{array}$ & & $\begin{array}{c}0.105^{\star} \\
(0.059)\end{array}$ & $\begin{array}{l}0.116^{\star \star} \\
(0.050)\end{array}$ & & $\begin{array}{c}0.104^{*} \\
(0.060)\end{array}$ \\
\hline father share time TV watch & & $\begin{array}{r}0.047 \\
(0.050)\end{array}$ & $\begin{array}{r}0.005 \\
(0.054)\end{array}$ & & $\begin{array}{r}0.047 \\
(0.051)\end{array}$ & $\begin{array}{r}0.005 \\
(0.053)\end{array}$ \\
\hline Predicted share & 0.101 & 0.111 & 0.105 & 0.100 & 0.111 & 0.104 \\
\hline \multicolumn{7}{|c|}{ GERMANY } \\
\hline \multirow[b]{2}{*}{ FIRST PART: $100 x \Delta$ prob(share>0) } & \multicolumn{3}{|c|}{ FEMALE } & \multicolumn{3}{|c|}{ MALE } \\
\hline & (spec 1) & (spec 2) & (spec 3) & (spec 1) & (spec 2) & (spec 3) \\
\hline mother TV watch time (dummy) & $\begin{array}{r}0.172^{\star \star \star} \\
(0.053)\end{array}$ & & $\begin{array}{r}0.143^{\star *} \\
(0.061)\end{array}$ & $\begin{array}{r}0.151^{\star \star *} \\
(0.050)\end{array}$ & & $\begin{array}{c}0.128^{* *} \\
(0.058)\end{array}$ \\
\hline father TV watch time (dummy) & & $\begin{array}{r}0.186^{\star \star \star} \\
(0.053)\end{array}$ & $\begin{array}{r}0.183^{\star \star \star} \\
(0.060)\end{array}$ & & $\begin{array}{r}0.143^{\star * *} \\
(0.042)\end{array}$ & $\begin{array}{r}0.161^{\star \star *} \\
(0.055)\end{array}$ \\
\hline Predicted prob(positive share) & 0.634 & 0.639 & 0.539 & 0.692 & 0.740 & 0.630 \\
\hline \multicolumn{7}{|l|}{ SECOND PART: $100 \times \Delta E($ share $\mid$ share $>0)$} \\
\hline mother share time TV watch & $\begin{array}{r}0.200 \text { *** } \\
(0.056)\end{array}$ & & $\begin{array}{r}0.187^{* \star *} \\
(0.061)\end{array}$ & $\begin{array}{r}0.238^{\star * \star} \\
(0.069)\end{array}$ & & $\begin{array}{r}0.208 * \star * \\
(0.068)\end{array}$ \\
\hline $\begin{array}{r}\text { father share time TV watch } \\
\text { Predicted share }\end{array}$ & & $\begin{array}{l}0.141^{\star \star} \\
(0.057)\end{array}$ & $\begin{array}{r}0.061 \\
(0.058)\end{array}$ & & $\begin{array}{l}0.160 * * \\
(0.064)\end{array}$ & $\begin{array}{r}0.068 \\
(0.065)\end{array}$ \\
\hline
\end{tabular}

See Notes to Table 6. 


\section{Conclusion}

We have modeled the allocation of time by young students, considering three different types of activities: studying and reading; socializing; watching TV. We provided an analysis of three countries (Italy, France and Germany) in a comparative framework.

Results indicate considerable similarity across countries in the association between parents and youngsters in the allocation of time to TV watching, possibly due to the synchronization of that activity within the household. Countries diverge, on the other hand, on the influence that parents' may have on youngsters time devoted to socializing and to reading and studying. Italy stands out as the country where the role of parents is more pronounced, in particular that of the mother.

Our analysis illustrates the operation of one channel so far disregarded when analyzing parental investment in children. Actions by the adolescents themselves in terms of the allocation of their time have implications for acquisition of human capital. Disentangling whether this association between parents and children time use results from a direct role model that parents play, from the transmission of preferences across generations, from the transmission of endowments/abilities, or from outside common influences, is beyond the scope of this paper, constrained as it is by the current data limitations.

\section{References}

Apps, Patricia and Ray Rees (2002) "Household production, full consumption and the costs of children." Labour Economics, 8: 621-648.

Becker, Gary S. and Nigel Tomes (1986) "Human capital and the rise and fall of families." Journal of Labor Economics, 4(3, part 2): S1-S39.

Bianchi, Suzanne M., John P. Robinson, and Melissa A. Milkie (2006) Changing Rhythms of American Family. New York: Russell Sage.

Blau, Francine D. and Adam J. Grossberg (1992) "Maternal labor supply and children's cognitive development." Review of Economics and Statistics, 74(3): 474-481.

Bleakley, Hoyt and Aimee Chin (2008) "What holds back the second generation? The intergenerational transmission of language human capital among immigrants." Journal of Human Resources, 43(2): 267-298..

Blow, Laura, Alissa Goodman, Greg Kaplan, Ian Walker, and Frank Windmeijer (2005) How important is income in determining children's outcomes? A methodology review of econometrics approaches. Mimeo.

Booth, Alison L. and Hiau Joo Kee (2006) "Intergenerational transmission of fertility patterns in Britain." IZA discussion paper 2437. Bonn: Institute for the Study of Labor.

Cawley, John and Feng Liu (2007) "Mechanisms for the association between maternal employment and child cognitive development." NBER working paper 13609.

Calvó-Armengol, Antoni and Matthew O. Jackson (forthcoming) "Like father, like son: social externalities and parent-child correlation in behavior." American Economic 
Journal Microeconomics.

Cragg, J.G. (1971) "Some statistical model for limited dependent variables with application to the demand for durable goods." Econometrica, 39. 829-844.

Cunha, Flavio and James Heckman (2007) "The technology of skill formation." American Economic Review, 97(2): 31-47.

Datcher-Loury, Linda (1988) "Effects of mother's home time on children's schooling." Review of Economics and Statistics, 70(3): 367-373.

Deb, P. and P. K. Trivedi (2002) "The structure of demand for health care: latent class versus two-part models." Journal of Health Economics, 21: 601-625.

Eisenberg, Marla E., R.E. Olson, D. Neumark-Sztainer, M. Story and L.H. Bearinger (2004) "Correlations between family meals and psychosocial well-being among adolescents." Pediatrics and Adolescent Medicine, 158(8): 792-796

Ermisch, John and Marco Francesconi (2002) "The effects of parents' employment on children's educational attainment." ISER working paper 2002-21.

Fernandez, Raquel, Alessandra Fogli, and Claudia Olivetti (2004) "Mothers and sons: Preference formation and female labor force dynamics." Quarterly Journal of Economics, 119(4): 1249-99.

Frey, Bruno S., Christine Benesch, and Alois Stutzer (2007) "Does watching TV make us happy?" Journal of Economic Psychology, 28: 283-313.

Gauthier, Anne H. , Jonathan Gershuny and Kimberly Fisher (2006) Multinational Time Use Study user's guide and documentation, version 2, February, Mimeo. Available at http://www.timeuse.org/mtus/documentation/

Gourieroux, Christian, Alain Monfort, and Alain Trognon (1984) "Pseudo maximum likelihood methods: Theory." Econometrica, 52(3): 681-700.

Haveman, Robert and Barbara Wolfe (1995) "The determinants of children's attainments: a review of methods and findings." Journal of Economic Literature, 33(4): 1829-1878.

Haveman, Robert, Barbara Wolfe and James Spaulding (1991) "Childhood events and circumstances influencing high school completion." Demography, 28(1): 133157.

Heckman, James J., Jora Stixrud, and Sergio Urzua (2006) "The effects of cognitive and noncognitive abilities on labor market outcomes and social behavior." Journal of Labor Economics, 24(3): 411-482.

Ichino, Andrea and Anna Sanz-de-Galdeano (2005) "Reconciling motherhood and work: evidence from time use data in three countries." in Daniel S. Hamermesh,and Gerard A. Pfann (eds.) The Economics of Time Use, Amsterdam, Elsevier.

Hill. M. Anne and June O'Neill (1994) "Family endowments and the achievement of young children with special reference to the underclass." Journal of Human Resources, 29(4): 1064-1100.

Holmlund, Helena, Mikael Lindahl, and Erik Plug (2008) The causal effects of parent's schooling on children's schooling: A comparison of estimation methods. IZA discussion paper 3630. Bonn: Institute for the Study of Labor.

Jones, Andrew M. (1989) "A double-hurdle model of cigarette consumption." Journal of Applied Econometrics, 4: 23-39.

Juster, Thomas F. and Frank P. Stafford (1991) "The allocation of time: Empirical findings, behavioral models, and problems of measurement." Journal of Economic Literature, 29(2): 471-522.

Kooreman, Peter (2007) "Time, money, peers, and parents; some data and theories on teenage behavior." Journal of Population Economics, 20: 9-33. 
Leibowitz, Arleen (1974) "Home investments in children." Journal of Political Economy, 82(2): S111-S131.

Leibowitz, Arleen (1977) "Parental inputs and children's achievements." Journal of Human Resources, 12(2): 242-251.

Lindbeck, Assar and Sten Nyberg (2006) "Raising children to work hard: altruism, work norms, and social insurance." Quarterly Journal of Economics, 121(4): 14731503.

Loureiro, Maria L., Anna Sanz-de-Galdeano, and Daniela Vuri (2006) "Smoking habits: like father, like son, like mother, like daughter." IZA discussion paper 2279. Bonn: Institute for the Study of Labor.

Multinational Time Use Study (MTUS) (2005). Created by Jonathan Gershuny, Kimberly Fisher and Anne H. Gauthier, with Alyssa Borkosky, Anita Bortnik, Donna Dosman, Cara Fedick, Tyler Frederick, Sally Jones, Tingting Lu, Fiona Lui, Leslie MacRae, Berenice Monna, Monica Pauls, Cori Pawlak, Nuno Torres and Charlemaigne Victorino. Version 5.5 .2 (released 14 October). ISER, University of Essex, Colchester, UK. Available at http://www.timeuse.org/mtus/

Neidell, Matthew J. (2000) "Early parental time investments in children's human capital development: effects of time in the first year on cognitive and non-cognitive outcomes." Working paper 806, University of California Los Angeles.

O'Brien, Margaret and Deborah Jones (1999) "Children, parental employment and educational attainment: an English case study." Cambridge Journal of Economics, 23: 599-621.

Papke, Leslie E. and Jeffrey M. Wooldridge (1996) "Econometric methods for fractional response variables with an application to 401 (K) plan participation rates." Journal of Applied Econometrics, 11(6):619-632.

Price, Joseph (2008) "Parent-child quality time: Does birth order matter?" Journal of Human Resources, 43(1): 240-265.

Ramalho, Joaquim J.S. and Jacinto Vidigal da Silva (2007) "A two-part fractional regression model for the capital structure decisions of micro, small, medium and large firms." Mimeo, Universidade de Évora.

Sénéchal, Monique and Jo-Anne LeFevre (2002) "Parental involvement in the development of children's reading skill: a five-year longitudinal study." Child Development, 73(2): 445-460.

Stafford, Frank P. and Jean Yeung (2005) "The distribution of children's developmental resources." in Daniel S. Hamermesh and Gerard A. Pfann (eds.) The Economics of Time Use, Amsterdam, Elsevier, p. 289-313.

Taveras, Elsie M., Sheryl L. Rifas-Shiman, Catherine S. Berkey, Helaine R.H. Rockett, Alison E. Field, A. Lindsay Frazier, Graham A. Colditz, and Matthew W. Gillman (2005) "Family dinner and adolescent overweight." Obesity Research, 13: 900906.

Vandewater, Elizabeth A., David S. Bickham, and June H. Lee (2006) "Time well spent? Relating television use to children's free-time activities." Pediatrics, 117(2): e181-e191.

Wilhelm, Mark, Eleanor Brown, Patrick Rooney, and Richard Steinberg (2004) "The intergenerational transmission of generosity." Mimeo, Center on Philanthropy at Indiana University. 


\section{APPENDIX}

Table A.1. Technical description of the Time Use Surveys, France (1998/1999), Germany (1991/1992) and Italy (1988/1989)

\begin{tabular}{|c|c|c|c|}
\hline & FRANCE & GERMANY & ITALY \\
\hline Response rate & $\begin{array}{l}\text { 91.1\% household response rate; } \\
88.3 \% \text { individual response rate }\end{array}$ & quota sample & $70 \%$ \\
\hline Number of diary days & 1-day & 2-day & 1-day \\
\hline Multi-member household survey & Yes & Yes & Yes \\
\hline Type of diary & $\begin{array}{l}\text { Fixed time slot completed on } \\
\text { the day the activities were performed }\end{array}$ & Fresh & Fresh \\
\hline Time interval in the diary & 10 minutes & 5-minutes & Free \\
\hline Data on secondary activities & Yes & Yes & Yes \\
\hline Data on where the activity was carried out & Yes & Yes & Yes \\
\hline Data on who else was present & Yes & Yes & No \\
\hline Number of activities coded & 139 & 231 & 150 \\
\hline Number of cases in the original file & 15,441 & 25,812 & 38,110 \\
\hline Number of valid diaries in the World5.5 file & 15,318 & 25,775 & 37,764 \\
\hline
\end{tabular}

Number of valid diaries in the World5.5 file

15,318

25,775

37,764

Sources: Technical Description on MTUS documentation (retrieved July 30, 2007); Gauthier et al. (2006). 
Table A.2. Time allocation activity codes (MTUS)

\begin{tabular}{|cl|cl|}
\hline MTUS Code & \multicolumn{1}{|c|}{ Content } & MTUS Code & \multicolumn{1}{c|}{ Content } \\
\hline AV1 & Formal work & AV21 & Walks \\
AV2 & Paid work at home & AV22 & At church \\
AV3 & Second job & AV23 & Civic organizations \\
AV4 & School/classes & AV24 & Cinema/theatre \\
AV5 & Travel to/from work & AV25 & Dance/party, etc. \\
AV6 & Cooking/washing up & AV26 & Social clubs \\
AV7 & Housework & AV27 & Pubs \\
AV8 & Odd jobs & AV28 & Restaurants \\
AV9 & Gardening & AV29 & Visiting friends \\
AV10 & Shopping & AV30 & Listening to radio \\
AV11 & Child care & AV31 & Watching TV \\
AV12 & Domestic travel & AV32 & Listening to music, etc. \\
AV13 & Dressing/toilet & AV33 & Study \\
AV14 & Receiving personal services & AV34 & Reading books \\
AV15 & Meals/snacks & AV35 & Reading papers/magazines \\
AV16 & Sleep/naps & AV36 & Relaxing \\
AV17 & Leisure travel & AV37 & Conversation \\
AV18 & Excursions, trips & AV38 & Entertaining friends \\
AV19 & Playing sport & AV39 & Knitting/sewing \\
AV20 & Watching sport & AV40 & Pastimes/hobbies \\
& & Unknown activity \\
\hline Source: Gauna & & \\
\hline
\end{tabular}

Source: Gauthier et al. (2006).

Table A.3. Sample sizes

\begin{tabular}{|lccc}
\hline & FRANCE & GERMANY & ITALY \\
\hline Student Diary & 846 & 650 & 655 \\
Student Mother's Diary & 805 & 629 & 635 \\
Student Father's Diary & 723 & 576 & 583 \\
Student and both Parents Diary & 682 & 555 & 563 \\
Households & 708 & 553 & 566 \\
\hline
\end{tabular}

Source: Authors' computation from Time Use Surveys. 
Table A.4. Activity contents and codes for the variables: studying and reading, socialization and TV watching, in France, Germany and Italy

\begin{tabular}{|c|c|c|c|c|c|}
\hline & \multirow{2}{*}{ ACTIVITY GROUP } & \multirow{2}{*}{$\begin{array}{c}\text { Original and } \\
\text { transformed } \\
\text { Codes of } \\
\text { MTUS }\end{array}$} & \multicolumn{3}{|c|}{ Time Use Survey specificities by country } \\
\hline & & & France & Germany & Italy \\
\hline \multicolumn{6}{|c|}{ STUDYING AND READING } \\
\hline & STUDENTS & & & & \\
\hline \multirow[t]{3}{*}{ ststrdng } & study at home & AV33 & AV33 & AV33 & AV33 \\
\hline & reading books and newspapers & $\begin{array}{l}\text { AV34 } \\
\text { AV35 }\end{array}$ & $\begin{array}{l}\text { AV34 } \\
\text { AV35 }\end{array}$ & $\begin{array}{l}\text { AV34 } \\
\text { AV35 }\end{array}$ & $\begin{array}{l}\text { AV34 } \\
\text { AV35 }\end{array}$ \\
\hline & PARENTS & & & & \\
\hline $\begin{array}{l}\text { mstrdng } \\
\text { fstrdng }\end{array}$ & $\begin{array}{l}\text { studying } \\
\text { reading books and newspapers }\end{array}$ & $\begin{array}{l}\text { AV33 } \\
\text { AV34 } \\
\text { AV35 } \\
\text { AV4 }\end{array}$ & $\begin{array}{l}\text { AV34 } \\
\text { AV35 } \\
\text { AV4 } \\
\text { AV33 }\end{array}$ & $\begin{array}{l}\text { AV34 } \\
\text { AV35 } \\
\text { AV4 } \\
\text { AV33 }\end{array}$ & $\begin{array}{l}\text { AV34 } \\
\text { AV35 } \\
\text { AV4 } \\
\text { AV33 }\end{array}$ \\
\hline \multicolumn{6}{|c|}{ SOCIALIZING } \\
\hline & STUDENTS & & & & \\
\hline stscocial & $\begin{array}{l}\text { active sports } \\
\text { civic activities } \\
\text { excursions } \\
\text { cinema theater } \\
\text { visiting friends } \\
\text { entertaining friends }\end{array}$ & $\begin{array}{l}\text { AV18 } \\
\text { AV19 } \\
\text { AV23 } \\
\text { AV24 } \\
\text { AV29 } \\
\text { AV38 }\end{array}$ & $\begin{array}{l}\text { AV18 } \\
\text { AV19 } \\
\text { AV23 } \\
\text { AV24 } \\
\text { AV29 } \\
\text { AV38 }\end{array}$ & $\begin{array}{l}\text { AV18 } \\
\text { AV19 } \\
\text { AV23 } \\
\text { AV24 } \\
\text { AV29 } \\
\text { [AV38 n.a.] }\end{array}$ & $\begin{array}{l}\text { AV18 } \\
\text { AV19 } \\
\text { AV23 } \\
\text { AV24 } \\
\text { AV29 } \\
\text { AV38 }\end{array}$ \\
\hline & PARENTS & & & & \\
\hline $\begin{array}{l}\text { msocial } \\
\text { fsocial }\end{array}$ & $\begin{array}{l}\text { active sports } \\
\text { civic activities } \\
\text { excursions } \\
\text { cinema theater } \\
\text { visiting friends } \\
\text { entertaining friends }\end{array}$ & $\begin{array}{l}\text { AV18 } \\
\text { AV19 } \\
\text { AV23 } \\
\text { AV24 } \\
\text { AV29 } \\
\text { AV38 }\end{array}$ & $\begin{array}{l}\text { AV18 } \\
\text { AV19 } \\
\text { AV23 } \\
\text { AV24 } \\
\text { AV29 } \\
\text { AV38 }\end{array}$ & $\begin{array}{l}\text { AV18 } \\
\text { AV19 } \\
\text { AV23 } \\
\text { AV24 } \\
\text { AV29 } \\
\text { [AV38 n.a.] }\end{array}$ & $\begin{array}{l}\text { AV18 } \\
\text { AV19 } \\
\text { AV23 } \\
\text { AV24 } \\
\text { AV29 } \\
\text { AV38 }\end{array}$ \\
\hline \multicolumn{6}{|c|}{ TV WATCHING } \\
\hline & STUDENTS & & & & \\
\hline sttv & TV watching & AV31 & AV31 & AV31 & AV31 \\
\hline & PARENTS & & & & \\
\hline $\begin{array}{l}m t v \\
f t v\end{array}$ & TV watching & AV31 & AV31 & AV31 & AV31 \\
\hline
\end{tabular}

Notes: in the variable names, the prefix $f$ refers to the father, $m$ to the mother, and st to the student. The AV references report the MTUS original codes (see Table A.2). The category Studying and Reading does not include, in the case of Germany, homework time (which is reported together with school time); on the other hand, it includes computer use (excluding computer games). 
Table A.5. Time use variables definition and descriptive statistics

\begin{tabular}{|c|c|c|c|c|c|c|c|c|c|c|}
\hline \multirow{2}{*}{ Name of variable } & \multirow[b]{2}{*}{ Definition } & \multicolumn{3}{|c|}{ FRANCE } & \multicolumn{3}{|c|}{ GERMANY } & \multicolumn{3}{|c|}{ ITALY } \\
\hline & & $\mathrm{N}$ & Mean & SD & $\mathrm{N}$ & Mean & SD & $\mathrm{N}$ & Mean & SD \\
\hline \multicolumn{11}{|c|}{ Time use of student } \\
\hline sh_strdng & $\begin{array}{l}\text { share time spent in study and } \\
\text { reading }\end{array}$ & 846 & 0,06 & 0,08 & 650 & 0,02 & 0,03 & 655 & 0,11 & 0,0 \\
\hline d_strdng & $\begin{array}{l}=1 \text { if share in study and reading is } \\
\text { positive ( } 0 \text { otherwise) }\end{array}$ & 846 & 0,67 & 0,47 & 650 & 0,52 & 0,50 & 655 & 0,86 & 0,3 \\
\hline sh_strdng_pos & share study reading defined only if $>0$ & 563 & 0,10 & 0,08 & 339 & 0,04 & 0,04 & 562 & 0,12 & 0,07 \\
\hline sh_social & \begin{tabular}{|l|l|} 
share time spent socializing &
\end{tabular} & 846 & 0,04 & 0,06 & 650 & 0,05 & 0,07 & 655 & 0,03 & 0,05 \\
\hline d_social & $\begin{array}{l}=1 \text { if share socializing positive (0) } \\
\text { otherw.) }\end{array}$ & 846 & 0,38 & 0,49 & 650 & 0,57 & 0,50 & 655 & 0,34 & 0,47 \\
\hline sh_social_pos & share socializing defined only if $>0$ & 325 & 0,09 & 0,07 & 370 & 0,09 & 0,07 & 222 & 0,08 & 0,05 \\
\hline$s h \_t v$ & share time spent $\mathrm{w}$ & 846 & 0,08 & 0,07 & 650 & 0,06 & 0,06 & 655 & 0,07 & 0,05 \\
\hline$d \_t v$ & $\begin{array}{l}=1 \text { if share watching TV is positive (0 } \\
\text { otherwise) }\end{array}$ & 846 & 0,79 & 0,41 & 650 & 0,77 & 0,41 & 655 & 0,83 & 0,38 \\
\hline$s h \_t v \_p o s$ & hing TV defined or & 670 & 0,10 & 0,07 & 503 & 0,08 & 0,06 & 543 & 0,08 & 0,4 \\
\hline \multicolumn{11}{|c|}{ Time use of mother } \\
\hline msh_strdng & share time spent reading & 805 & 0,01 & 0,03 & 629 & 0,03 & 0,06 & 635 & 0,01 & 0,03 \\
\hline md_strdng & $\begin{array}{l}=1 \text { if share reading positive }(0 \\
\text { otherwise) }\end{array}$ & 805 & 0,33 & 0,48 & 629 & 0,63 & 0,48 & 655 & 0,28 & 0,45 \\
\hline msh_stdng_f & share of reading defined only if $>0$ & 262 & 0,04 & 0,04 & 398 & 0,05 & 0,06 & 163 & 0,04 & 0,0 \\
\hline$m s h$ & share time spent watching TV & 789 & 0,07 & 0,06 & 629 & 0,05 & 0,05 & 635 & 0,06 & 0,0 \\
\hline md_social & $\begin{array}{l}=1 \text { if share watch TV positive (0 } \\
\text { otherw.) }\end{array}$ & 805 & 0,72 & 0,45 & 629 & 0,75 & 0,43 & 635 & 0,80 & 0,40 \\
\hline msh_social_pos & atching TV defined only if $>0$ & 576 & 0,09 & 0,06 & 474 & 0,07 & 0,05 & 506 & 0.08 & 0,0 \\
\hline msh_tv & share time spent socializing & 805 & 0,02 & 0,04 & 629 & 0,03 & 0,06 & 635 & 0,02 & 0,0 \\
\hline$m d \_t v$ & $\begin{array}{l}=1 \text { if share socializing positive }(0 \\
\text { otherw.) }\end{array}$ & 805 & 0,34 & 0,47 & 629 & 0,45 & 0,50 & 635 & 0,29 & 0,46 \\
\hline$m s h \_t v \_p o s$ & share socializing defined only if $>0$ & 276 & 0,06 & 0,06 & 281 & 0,07 & 0,07 & 181 & 0,06 & 0,05 \\
\hline \multicolumn{11}{|l|}{ Time use of father } \\
\hline fsh_strdng & share time spent reading & 723 & 0,01 & 0,03 & 576 & 0,03 & 0,04 & 583 & 0,02 & 0,03 \\
\hline fd_strdng & $\begin{array}{l}=1 \text { if share reading is positive (0) } \\
\text { otherwise) }\end{array}$ & 723 & 0,30 & 0,46 & 576 & 0,60 & 0,49 & 655 & 0,44 & 0,50 \\
\hline fsh_stdng_pos & share of reading defined only if $>0$ & 216 & 0,04 & 0,04 & 346 & 0,04 & 0,05 & 214 & 0,05 & 0,04 \\
\hline fsh_social & share time spent watching TV & 723 & 0,08 & 0,07 & 576 & 0,06 & 0,06 & 583 & 0,07 & 0,05 \\
\hline fd_social & $\begin{array}{l}=1 \text { if share watch TV positive (0 } \\
\text { otherw.) }\end{array}$ & 723 & 0,81 & 0,39 & 576 & 0,82 & 0,39 & 655 & 0,86 & 0,34 \\
\hline fsh_social_pos & share watching TV defined only if $>0$ & 586 & 0,10 & 0,06 & 470 & 0,08 & 0,05 & 494 & 0,09 & 0,05 \\
\hline fsh_tv & share time spent socializing & 723 & 0,02 & 0,05 & 576 & 0,03 & 0,06 & 583 & 0,01 & 0,04 \\
\hline$f d \_t v$ & $\begin{array}{l}=1 \text { if share socializing positive }(0 \\
\text { otherw.) }\end{array}$ & 723 & 0,28 & 0,45 & 576 & 0,38 & 0,49 & 655 & 0,27 & 0,44 \\
\hline$f s h \_t v \_p o s$ & share socializing defined only if $>0$ & 203 & 0,07 & 0,06 & 218 & 0,08 & 0,07 & 102 & 0,07 & 0,06 \\
\hline
\end{tabular}

Source: Authors' computations from Time Use Surveys. 
Table A.6. Description of additional covariates used in regression analysis

\begin{tabular}{|c|c|c|c|c|c|c|c|c|c|c|}
\hline \multirow[b]{2}{*}{ Name of variable } & \multirow[b]{2}{*}{ Definition } & \multicolumn{3}{|c|}{ FRANCE } & \multicolumn{3}{|c|}{ GERMANY } & \multicolumn{3}{|c|}{ ITALY } \\
\hline & & $\mathrm{N}$ & Mean & SD & $\mathrm{N}$ & Mean & SD & $\mathrm{N}$ & Mean & SD \\
\hline \multicolumn{11}{|c|}{ Characteristics of students $(Z)$} \\
\hline female & $=1$ if female (0 otherwise) & 846 & 0.50 & 0.50 & 650 & 0.49 & 0.50 & 655 & 0.51 & 0.50 \\
\hline age & age of the student (years) & 846 & 16.8 & 1.3 & n.a. & n.a. & n.a. & 655 & 17.7 & 1.4 \\
\hline higheduc & above secondary education & 846 & 0.09 & 0.28 & 650 & 0.06 & 0.23 & 655 & 0.15 & 0.36 \\
\hline \multicolumn{11}{|c|}{ Characteristics of mother and father $(P)$} \\
\hline mage & mother's age & 805 & 43.74 & 5.42 & 629 & 43.50 & 5.61 & 635 & 44.03 & 5.69 \\
\hline mwork & $=1$ if mother work (part or full time) & 805 & 0.56 & 0.50 & 629 & 0.66 & 0.48 & 635 & 0.45 & 0.50 \\
\hline mwork_sh & share spent by mother working & 805 & 0.17 & 0.18 & 629 & 0.15 & 0.17 & 635 & 0.10 & 0.14 \\
\hline mseceduc & mother completed secondary educ & 805 & 0.48 & 0.5 & 629 & 0.62 & 0.49 & 635 & 0.68 & 0.47 \\
\hline mhigheduc & mother above secondary education & 805 & 0.30 & 0.46 & 629 & 0.30 & 0.46 & 635 & 0.23 & 0.42 \\
\hline fage & father's age & 723 & 46.07 & 6.26 & 576 & 46.99 & 6.25 & 583 & 48.11 & 6.07 \\
\hline fwork & $=1$ if father work (part or full time) & 723 & 0.72 & 0.45 & 576 & 0.93 & 0.25 & 583 & 0.88 & 0.33 \\
\hline fwork_sh & share spent by father working & 723 & 0.31 & 0.19 & 576 & 0.35 & 0.16 & 583 & 0.29 & 0.15 \\
\hline fseceduc & father completed secondary educ & 723 & 0.54 & 0.50 & 576 & 0.44 & 0.49 & 583 & 0.65 & 0.48 \\
\hline fhigheduc & father above secondary educ & 723 & 0.27 & 0.44 & 576 & 0.52 & 0.50 & 583 & 0.23 & 0.42 \\
\hline \multicolumn{11}{|c|}{ Characteristics of the household $(H)$} \\
\hline nosibl & $=1$ student with no siblings (0 otherwise) & 846 & 0.27 & 0.45 & 650 & 0.29 & 0.46 & 655 & 0.41 & 0.49 \\
\hline ncompgt3 & $=1 \mathrm{hh} . \mathrm{w} /$ more than 3 components ( 0 otherw.) & 846 & 0.74 & 0.44 & 650 & 0.71 & 0.45 & 655 & 0.83 & 0.38 \\
\hline msingpar & $=1$ mother single parent $(0$ otherwise $)$ & 805 & 0.13 & 0.33 & 629 & 0.10 & 0.29 & 635 & 0.06 & 0.23 \\
\hline fsingpar & $=1$ father single parent ( 0 otherwise) & 723 & 0.03 & 0.17 & 576 & 0.02 & 0.15 & 583 & 0.01 & 0.11 \\
\hline
\end{tabular}

Source: Authors' computations from Time Use Surveys.

Notes: For Germany age is not a continuous variable; the original variable in MTUS takes only two values: 15 and 19 : Therefore, the mean is not presented and the variable is excluded from the set of regressors. 